\title{
DES MOINES RIVER, AND ORIGIN OF THE NAME.
}

BY CHARLES R. KEYES, PH. D.

The Des Moines river is the largest watercourse that Iowa can call all her own. Rising on the northern border of the State, in the northwestern part, it flows entirely across, to the extreme southeast corner. At the present day the stream is much smaller than formerly. It is of no use for navigation; and its waterpowers are as yet scarcely noticed.

In the early days of Iowa's statehood the Des Moines river was considered a very pretentious stream. During the spring floods steamboats from the Mississippi came up regularly, as far as the Raccoon fork. Smaller steamers plied between that point and Ft. Dodge. In order to make the river more suitable for boats at all times an elaborate system of slack-water navigation was proposed, and begun with governmental aid. Careful surveys were made, and sites for dams were located at proper intervals. Several of these constructions were commenced, but only one was actually finished before the whole undertaking was given up.

At a still earlier date, at the beginning of the century, the Des Moines river was one of the principal routes of travel to and from the Northwest. St. Louis was the great trading post of the region. The Indians and French voyageurs paddled their canoes upstream, passing through the several little lakes near the headwaters, and then on to the Hudson Bay region. This was a waterway practically unobstructed from the northern Fur country to the lower Mississippi. Its importance at that time was greater than either the Mississippi, or the Missouri river.

Still earlier, when the interior of America was a veritable terra incognita, a far greater importance was ascribed to our simple, placid Des Moines. It was regarded as the greatest river on the continent. On the maps of the time the Mississippi drainage system is represented as a huge trident, reaching up from the Gulf. Few or no branches are shown. The Des Moines river forms the great central prong, much 
larger than either of the other two-the Mississippi and the Missouri. (See figure 1.)

On maps published a little while previous our Des Moines has swollen to a mighty waterway, with headwaters in the Saskatchewan region and the present province of British Columbia, draining two great lakes the size of Lake Superior, and finally uniting, near its present mouth, with two comparatively small streams, the Mississippi and the Missouri, the former rising in what is at the present time southeastern Wisconsin, and the latter in eastern Kansas not far from Kansas City. The Des Moines is the great middle river. The signification of this will soon appear.

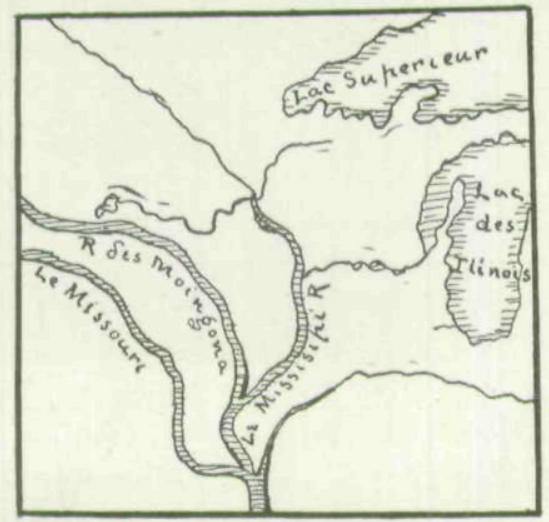

FIG. 1. PART OF CARTE DU CANADA PAR DE LISLE-PARIS, 1703.

The earliest reference to the Des Moines river appears to be Joliet's. On his map of 1674 the stream is called the Ouacuiatanas. The map was made by Joliet in Montreal, soon after his return from his explorations, with Marquette, in the Mississippi valley. It is probably the first map of the region that is based upon definite knowledge. From this period to the present, various names and various spellings of the one that has survived, have been followed.

The word Des Moines is manifestly of French origin. It is commonly interpreted "of the monks;" and the stream the "river of the monks." Some of the various spellings to be noted are De Moin, Des Moins, Demoin, De Moyen, Demoir, 
and Demon. The allusion to the Trappist monks has found general favor.

Another suggestion has also been offered. It is a French derivation of the word from the Algonkin name Moingona. The first use of this name seems to be on Franquelin's "Carte de la Louisiane," published in 1688. It is based upon La Salle's explorations. The name appears on many maps printed afterwards, even down to the time of Iowa's admission into the Union. The name is still preserved in the town of Moingona, on the right bank of the river, in Boone county. Cones, in summing up the opinions of the supposed origin

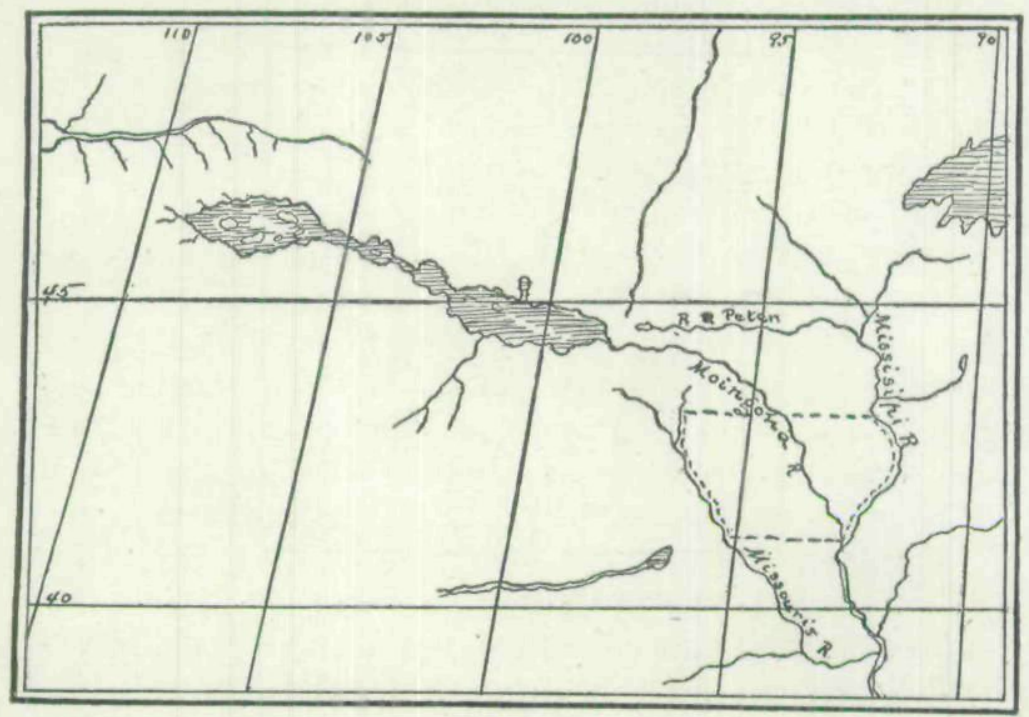

FIG. 2. PART OF THE SENEX MAP OF NORTH AMERICA- -LONDON, 1710.

of the name from this source, says that "The Indians called their place Moingona, Moingonan, or Mouingouinas-a word found in some form on very old maps. Later, the French clipped the word to Moin, calling the people les Moins, and their river la riviere des Moines, by spurious etymology. Traces of this history of the name survive in its various spellings."

As a rule the English maps of the region and the French maps based upon data obtained through Canadian sources 
adhere to the name Moingona for the Des Moines river. The Delisle "Carte du Canada ou de la Nouvelle France" published in 1707, and which was the work of two of the most noted eartographers of the time, the l'Isle "Carte de la Louisiane et du Cours du Mississippi," printed in Amsterdam in 1722, and the Sinex "Map of North America," 1710, all have $\mathrm{R}$. de Moingona. Towards the close of the eighteenth century some of the cartographic sketches of the region, as the Winterbotham map of 1795 for example, which is practically a summary to the knowledge of the region previous to the Lewis and Clarke explorations under the auspices of the United States government, have the name reduced to merely Moin.

The general opinion that has long prevailed in regard to the word Des Moines meaning "of the Monks" is probably due largely to the explanation given by Maj. Pike in his accounts of his explorations in the upper Mississippi valley in the years 1805 to 1807 . He calls particular attention to the riviere de Moyen (pronounciation scarcely distinguishable from des Moines) as it is lettered on many of the maps of that time, and so called by the voyageurs and traders. $\mathrm{He}$ goes on to give the derivation and application of the word, finally making it out to be a corruption of riviere des Moines or "river of the monks."

The use of the word de Moyen in the latter part of the last century and the early part of this has a significance that appears to have escaped notice. We get a hint from Featherstonhaugh in regard to a familiar geographic name, the origin of which is more intricate than the term under consideration. In his "Excursion through the Slave States," in 1834-5, he makes the remark, concerning the word Ozark now generally applied to the elevated and mountainous country lying in Missouri and Arkansas between the Missouri and Red rivers, and the Mississippi and Neosho rivers, that "It was the custom of the French Canadians to abbreviate all their names. If they were going to the Arkansas mountains they would say that they were going Aux Ares, 
and thus these highlands have obtained the name of Ozarks from American travelers."

Judging from what is known of the literature and customs of the same time it would appear that our Des Moines has an origin very much the same as Ozark and a number of other words. The phrase de moyen with its pronounciation almost indistinguishable from that of the word as we now know it, means "from the middle"-country being understood. So the French voyageurs on arriving at the great trading post of St. Louis, when speaking of the part of the region from whence they had come, naturally replied in the usual abbreviated form "de Moyen." The great middle country between the Missouri and the Mississippi and occupied by the great middle river was really a very appropriate title. The middle country, or middle valley, was indeed, as already stated, a very great valley, in the opinion of these early travelers - the greatest of the three, thought by some to extend to the Saskatchewan. The name de Moyen thus came to be attached in the same way as the title Ozark.

The transition of de Moyen to des Moins, as understood by Pike and others, to mean "of the monks" and finally to Des Moines, is simple, and readily accounted for when the French pronounciation of the words is also taken into consideration.

It might tax the ingenuity of the student of French to trace the descent of some of our geographic names, and in many cases he would doubtless have to give up in despair, unless he were to study the maps and literature of the time when the geography of the region was in its formative stage.

The etymologies were spurious often to a marvelous extent. Names that we are familiar with today were fearfully and wonderfully made. Two instances will suffice. The stream Rob Ruly, in Missouri, was originally Bois Brule. The creek Jack West, in Van Buren county, Iowa, was formerly Chequest.

Besides the Algonkin name Moingona and the corrupted French Des Moines, there are two other titles of Iowa's chief river that deserve mention in this place. One is Keosauqua, 


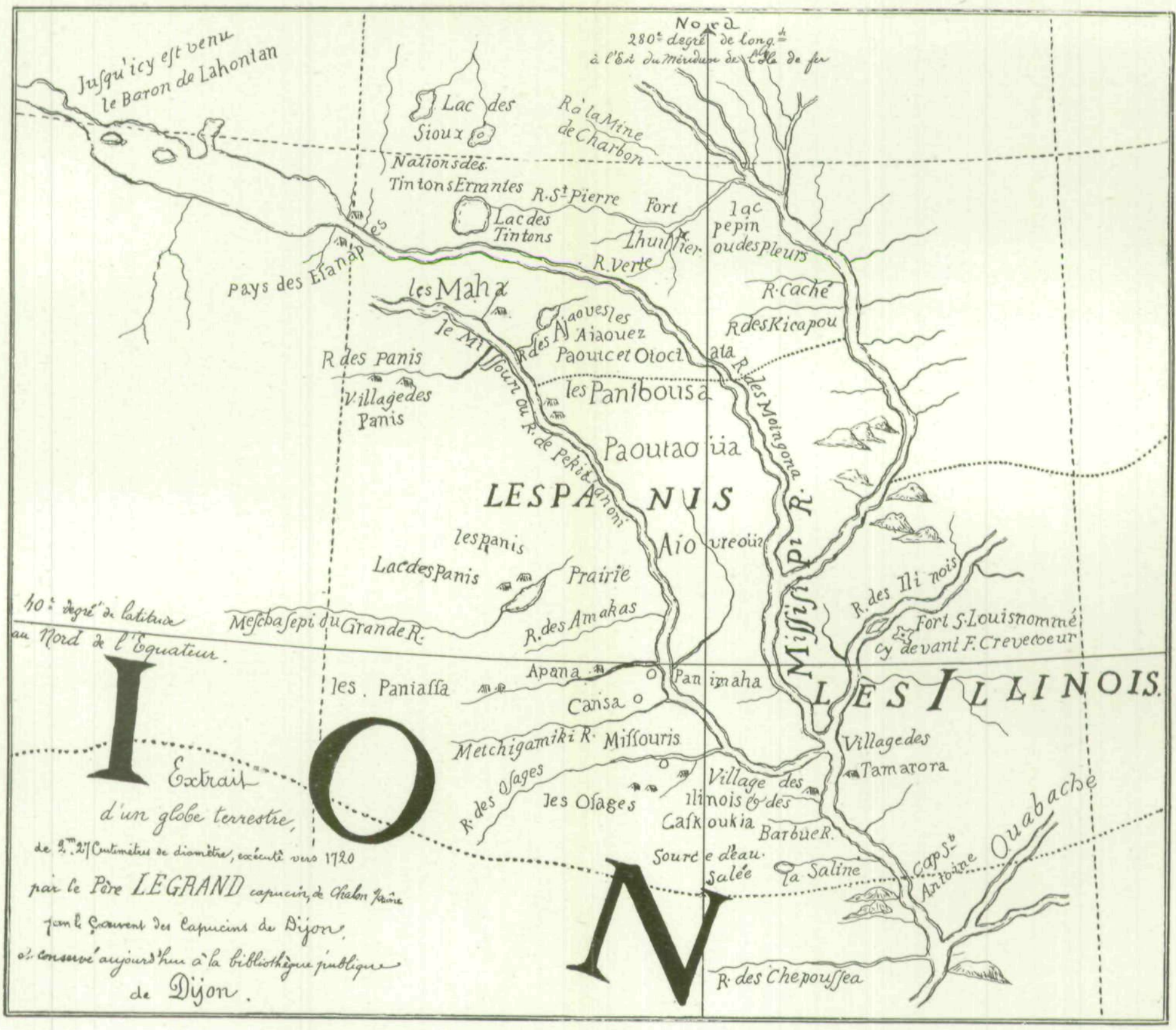

MAP OF THE IOWA PORTION OF THE UPPER MISSISSIPPI VALLEY -1720. 
or Keoskawqua as it is lettered in "Galland's Map of Iowa" of 1840. The principal town on the stream was at one time Keosauqua in Van Buren county.

Another title for the stream is the Sioux name Inyanshashawatpa, meaning Redstone river. The appropriateness of the term might not be inferred except by those who are well acquainted with the course of the Des Moines. In Marion county, in the central part of the State, the river flows through a deep canyon of red sandstone. The gorgeous vermillion eliffs attract wide attention. In the days when the river was the great highway to the Northwest they were the wonder of all. Many a traveler has gone into ecstacies over their majestic splendor, and has speculated wildly upon their origin. Today the little, almost deserted, village of Red Rock lies nestled under one of the most brilliantly colored walls. It was once an important landing for boats. A railroad now runs down the river valley for many miles, but at the great Red Rock it makes a wide detour inland through deep ravines, passing around this interesting spot, and the tourist just misses the most gorgeously picturesque bit of scenery found anywhere in all the Mississippi valley.

For the large map which accompanies the foregoing article THE ANNaLs is indebted to the Rev. Father Philip Laurent, Catholic Priest, of Muscatine, Iowa, who many years ago had it copied directly from a large terrestrial globe nearly seven feet in diameter, made about the year 1720, by the Capuchin Monk, Pere Legrand, of Chalon, department of Saone, France. This globe is now in the Capuchin convent in Dijon. The copy was made at the request of Father Laurent, by the public librarian of that place. This is one of the earliest maps in which the present geographic features of the Mississippi Valley are recognized.-EDrton of ThE ANnals.

The Abolitionists of Linn county held a meeting at the court house in Marion on the 30th ult., and formed a society, the proceedings of which, together with the constitution, appear in the last number of The Standard. We have looked them over and were pleased to see that the names of none of our numerous subscribers appear in the proceedings, so we infer that it is confined to a few fanatics who belong to the Whig party.-Bloomington Herald, Jan. 20, 1843. 
Copyright of Annals of Iowa is the property of State of Iowa, by \& through the State Historical Society of Iowa and its content may not be copied or emailed to multiple sites or posted to a listserv without the copyright holder's express written permission. However, users may print, download, or email articles for individual use. 